\title{
OCCURRENCE OF KILLER CANDIDA GLABRATA CLINICAL ISOLATES
}

\author{
Arroyo-Helguera $\mathrm{O}^{1, *}$, De Las Penas Alejandroº , Castaño Irene ${ }^{2}$ \\ ${ }^{1}$ Instituto de Salud Pública, Universidad Veracruzana, Av. Luís Castelazo Ayala S/N, Industrial Animas, 91190 Xalapa, Veracruz, \\ México; ${ }^{2}$ División de Biología Molecular, Instituto Potosino de Investigación Científica y Tecnológica, Camino a la Presa San \\ José 2055, Lomas 4 sección, 78216 San Luis Potosí, México.
}

Submitted: January 14, 2011; Returned to authors for corrections: August 18, 2011; Approved: June 07, 2012.

\begin{abstract}
In this work we characterized the occurrence of killer activity in 64 Candida glabrata clinical isolates under different conditions. We found that only $6.25 \%$ of the clinical isolates tested were positive for killer activity against a Saccharomyces cerevisiae W303 sensitive strain. Sensitivity of killer activity to different values of $\mathrm{pH}$ and temperatures was analyzed. We found that the killer activity presented by all isolates was resistant to every $\mathrm{pH}$ and temperature tested, although optimal activity was found at a range of $\mathrm{pH}$ values from 4 to 7 and at $37^{\circ} \mathrm{C}$. We did not observe extrachromosomal genetic elements associated with killer activity in any of the positive $C$. glabrata isolates. The killer effect was due to a decrease in viability and DNA fragmentation in sensitive yeast.
\end{abstract}

Key words: Candida glabrata; killer activity; yeast; Saccharomyces

\section{INTRODUCTION}

C. glabrata has emerged as an important pathogen in humans and now is the second most common Candida species isolated from bloodstream infections, after Candida albicans $(17,18)$. This emergence has been attributed to a low susceptibility to azole compounds and to the high rate at which C. glabrata develops resistance to antifungals, requiring the use of alternative antifungal therapy $(5,6,15,19,22)$. Some yeast strains of Candida and other genera secrete into the extracellular medium proteins or glycoproteins also known as killer toxins with toxic effects on sensitive yeasts (1). It has been reported that the capacity to produce killer proteins can confer advantage over sensitive strains when competing for nutrients available in their host or in the environment (25). Several studies propose such killer proteins as potential novel antimycotic biocontrol agents for fungal pathogens and for treatment of human fungal infections $(20,26)$. In C. glabrata Muller et al. (16) reports three killer yeast from 182 human clinical isolates, but none of this killer yeast or killer toxin properties were characterized.

Killer proteins were described first in Saccharomyces cerevisiae and soon after in many other yeast such as Candida, Cryptococcus, Debaryomyces, Kluyveromyces, etc. The genetic elements that encode for a killer phenotype are double stranded RNA molecules (dsRNA) encapsulated in virus like particles, linear double stranded DNA plasmids (dsDNA) or nuclear genes (23) and these genetic elements that encode for killer 
proteins have been isolated from several yeast genera, and killer phenotypes are classified into at least 11 groups $(27,30)$. The mechanisms by which killer toxins kill sensitive yeast are: disruption of the membrane function through ion channel formation (9), blockage DNA synthesis, and arrest in the G1 phase of the cell cycle and by caspase-mediated apoptosis (21).

In this work, we analyzed the occurrence of killer phenotype in a collection of 64 clinical isolates of C. glabrata and we partially characterized the killer toxin, including $\mathrm{pH}$ and temperature sensitivity of the killer activity. We also determined the presence of extra chromosomal genetic elements and killer effect in yeast viability.

\section{MATERIALS AND METHODS}

\section{Strains}

Laboratory strains and human clinical isolates used in this work are described in Table 1.

Table 1. Strains used in this study.

\begin{tabular}{|c|c|c|c|}
\hline Strain & Parent & Genotype & Source or Reference \\
\hline Saccharomyces cerevisiae & W303 & $\begin{array}{l}\text { MATa ura3-1 leu2-3,112 his3- } \\
11,15 \text { trpl ade2-1 ade3::hisG }\end{array}$ & $\begin{array}{l}\text { Lab collection } \\
\text { (IPICYT) }\end{array}$ \\
\hline $\begin{array}{l}\text { Saccharomyces cerevisiae } \\
\text { (Containing a } 4.5 \mathrm{~Kb} \text { dsRNAs) }\end{array}$ & $\mathrm{S} 288 \mathrm{C}$ & $\alpha \mathrm{MKT}^{+}$ & $(28)$ \\
\hline Candida glabrata $\mathrm{BG} 14$ & $\mathrm{BG} 1$, clinical isolate & $\begin{array}{l}\text { ura3s::Tn903 G418 } \\
\text { killer - }\end{array}$ & (2) \\
\hline Candida glabrata CBS138 & Clinical isolate & killer + & Reference strain (ATCC2001) \\
\hline $\begin{array}{l}\text { clinical isolates } 1 \text { through } 64 \\
\text { MC1 through MC64 }\end{array}$ & Clinical isolates & & (Lavaniegos-Sobrino et al. 2009) \\
\hline
\end{tabular}

\section{Culture media}

All yeast were grown in standard yeast media YEPD broth containing $10 \mathrm{~g} / \mathrm{L}$ yeast extract, $20 \mathrm{~g} / \mathrm{L}$ peptone, $2 \%$ glucose were supplied by Fisher. YPD-MB agar (YPD containing $0.01 \%$ methylene blue and $2.0 \%$ agar) was used for killer phenotype determination. YPD with $2.0 \%$ agar was used for viability assay.

\section{Toxin crude extracts preparation and determination of killer activity}

Killer cells were inoculated from stock culture and grown in $250 \mathrm{~mL}$ Erlenmeyer flasks containing $100 \mathrm{~mL}$ of YEPD medium at $30^{\circ} \mathrm{C}$ and 200 r.p.m. of shaking. Samples of $10 \mathrm{~mL}$ of C. glabrata culture samples were centrifuged at $3500 \mathrm{rpm}$ for $10 \mathrm{~min}$ at $4^{\circ} \mathrm{C}$. The supernatant was filtered through sterile $0.22 \mu \mathrm{m}$ pore size polivinyliden fluoride membrane (Millipore). A volume of ethanol was added to the cell-free supernatant to achieve a final concentration of $70 \% \mathrm{v} / \mathrm{v}$, incubated $4^{\circ} \mathrm{C}$ for $1 \mathrm{~h}$ and centrifuged at $16,000 \mathrm{~g}$ for $40 \mathrm{~min}$. The pellet was dried and resuspended in $1 \mathrm{~mL}$ of citrate/phosphate buffer $(1 \mathrm{mM}$ sodium citrate/phosphate $\mathrm{pH}$ 7). Killer extracts were maintained at $-20^{\circ} \mathrm{C}$. To evaluate killer activity, $100 \mu 1$ of killer extracts were impregnated on filters (8 $\mathrm{mm}$ diameter) placed on YPD-MB agar plates; each inoculated with $1 \times 10^{6}$ cells of the sensitive strain $S$. cerevisiae W303. The plates were incubated at $30^{\circ} \mathrm{C}$ for $72 \mathrm{~h}$. The killer strains were identified by the presence of a death halo (precipitate of methylene blue) of the sensitive cells surrounding the filter containing the killer extract. The diameter of the inhibition zone around each filter was measured and the area was calculated.

\section{Effect of the pH and temperature on killer activity}

In order to analyze the effect of $\mathrm{pH}$ on killer toxin activity, killer yeast were grown in YEPD medium adjusted to different $\mathrm{pH}$ values ranging from 4-9 with citrate-phosphate buffer, then 
killer extracts and were obtained maintained at $-20^{\circ} \mathrm{C}$. Killer extracts from killer yeast grown at $\mathrm{pH} 7.0$ were adjusted to different $\mathrm{pH}$ values ranging from 4 to 9 and then $100 \mu \mathrm{L}$ aliquots of the samples were added to determine killer activity on YPDMB agar, previously plated with the sensitive yeast suspension. Three plates of each $\mathrm{pH}$ were incubated at $25,28,30,37^{\circ} \mathrm{C}$ for $72 \mathrm{~h}$.

\section{Extraction of total nucleic acids and DNA fragmentation assay}

Cells were collected by centrifugation at $3500 \mathrm{rpm}$ for 10 min, resuspended in lysis buffer (50 mM Tris, $10 \mathrm{mM}$ EDTA, 150 $\mathrm{mM} \mathrm{NaCl}, 1 \%$ Triton and 1\% $\quad$ SDS) plus $500 \mu \mathrm{L}$ of phenol:chloroform:isoamylic alcohol (25:24:21) followed by incubation at $44{ }^{\circ} \mathrm{C}$ for $30 \mathrm{~min}$. The aqueous phase was recovered and washed twice with 1 volume of cold ethanol and the pellet was resuspended in $10 \mathrm{mM}$ Tris. For DNA fragmentation assays, total DNA was extracted from $S$. cerevisiae (W303) treated cells as described previously with modifications (3). Briefly, cells were collected by centrifugation at $3500 \mathrm{rpm}$ for $10 \mathrm{~min}$, resuspended in lysis buffer and $0.5 \mathrm{~mm}$ zirconia beads (Biospec Products). DNA was extracted as described above. The pellet was resuspended in $10 \mathrm{mM}$ Tris with $1 \mathrm{mg} / \mathrm{ml} \mathrm{RNase}$ and incubated at $37^{\circ} \mathrm{C}$ for $0.5 \mathrm{~h}$. Ethanol (95\% v/v) and $3 \mathrm{M}$ sodium acetate solution ( $\mathrm{pH}$ 5.2) was added and the samples were stored at $20^{\circ} \mathrm{C}$ overnight. The DNA samples were analyzed by electrophoresis on a $1 \%$ agarose gel (at $60 \mathrm{~V} / 30 \mathrm{~mA}$ ). $1 \mathrm{~kb}$ DNA ladder (Invitrogen) was used as marker. The gel was visualized on a gel-doc system (Biorad) after staining with ethidium bromide.

\section{Curing of nucleic acids}

The killer yeasts were plated on YPD-agar plates at a density of $10^{7}$ cells/plate and was subjected to ultraviolet light irradiation $(254 \mathrm{~nm}$ ) at a dose of $20,000 \mu \mathrm{J} / \mathrm{cm} 2$ for $10 \mathrm{~s}$ (lethality about 80 98\%) with a UV cross-linker (Stratalinker UV). The UV-irradiated plates were incubated at $30^{\circ} \mathrm{C}$ for 4 days. The presence or absence of plasmid was examined by electrophoresis of nucleic acids. As positive control for plasmid curing, we used a strain that contains a $4.5 \mathrm{~kb}$ double-stranded RNAs (dsRNAs) from ( $S$. cerevisiae strain S288C) (28).

\section{Cell viability assay}

To examine killer toxin activity in liquid media, yeast strains were inoculated in YPD medium and incubated with shaking at $30^{\circ} \mathrm{C}$ in the presence or absence of the killer extracts for 72 hours, serial dilutions of each culture were made and aliquots were plated onto YPD agar plates. The colony forming units (CFU) of the yeast was evaluated after 3 days of incubation at $30^{\circ} \mathrm{C}$, the results were expressed as \% CFU of treated yeast cells compared with untreated control cells.

\section{Statistical analysis}

Cell viability results are presented as mean \pm S.D. of minimal three independent measurements. In addition, Tukey test was employed for further determination of the significance of differences between control and treated cells.

\section{RESULTS}

\section{Killer activity of some Candida glabrata clinical isolates}

We screened 64 clinical isolates from C. glabrata for ability to kill sensitive $S$. cerevisiae strain W303. We found that only four $(6.25 \%)$ of all the clinical isolates showed killer activity and by comparison, C. glabrata CBS-138 (ATCC2001) a previously identified killer yeast (16) produced more killer activity than any of the four clinical isolates identified in this study. Only the killer activity from clinical isolates MC28 was lower than the other isolates (Fig. 1).

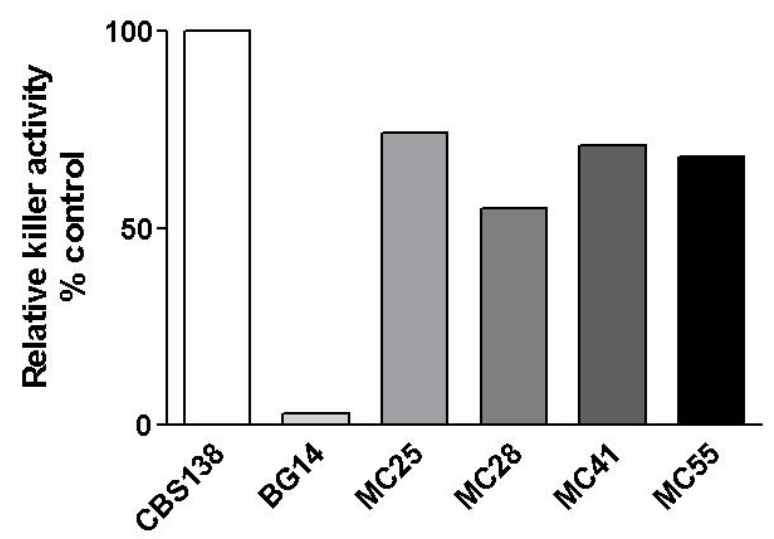

Figure 1. Killer activity of four C. glabrata clinical isolates. Killer yeast (CBS138), killer yeast negative (BG14). $n=5$. 


\section{Effect of pH and temperature on killer activity}

As shown in Fig. 2, killer yeast extracts were adjusted to $\mathrm{pH}$ values of 4-9 in order to analyze the effect of $\mathrm{pH}$ on killer protein stability. We found that killer activity was almost constant over the $\mathrm{pH}$ range tested and little difference was observed when C. glabrata culture media used for the cultivation of the clinical isolates had their $\mathrm{pH}$ adjusted at 4 to 7 , but at $\mathrm{pH}$ values from 8 to $9 \mathrm{pH}$ killer activity was reduced considerably. Fig. 3 shows the effect of changes in $\mathrm{pH}$ on the secretion of killer toxin by $C$. glabrata strains grown at different $\mathrm{pH}$ values. Secretion of killer toxin by all producing C. glabrata clinical isolates was constant between $\mathrm{pH}$ values from 4 to 7 , while secretion was markedly decreased when $C$. glabrata clinical isolates were grown at $\mathrm{pH}$ values from 8 to 9 .

We then determined whether killer activity was affected by the temperature of incubation during the growth assay. As shown in Fig. 4, culture extracts from all C. glabrata clinical isolates and from the positive control CBS138, showed stronger killer activity when $S$. cerevisiae sensitive yeast was grown at $37^{\circ} \mathrm{C}$ and $28^{\circ} \mathrm{C}$ or $30^{\circ} \mathrm{C}$.

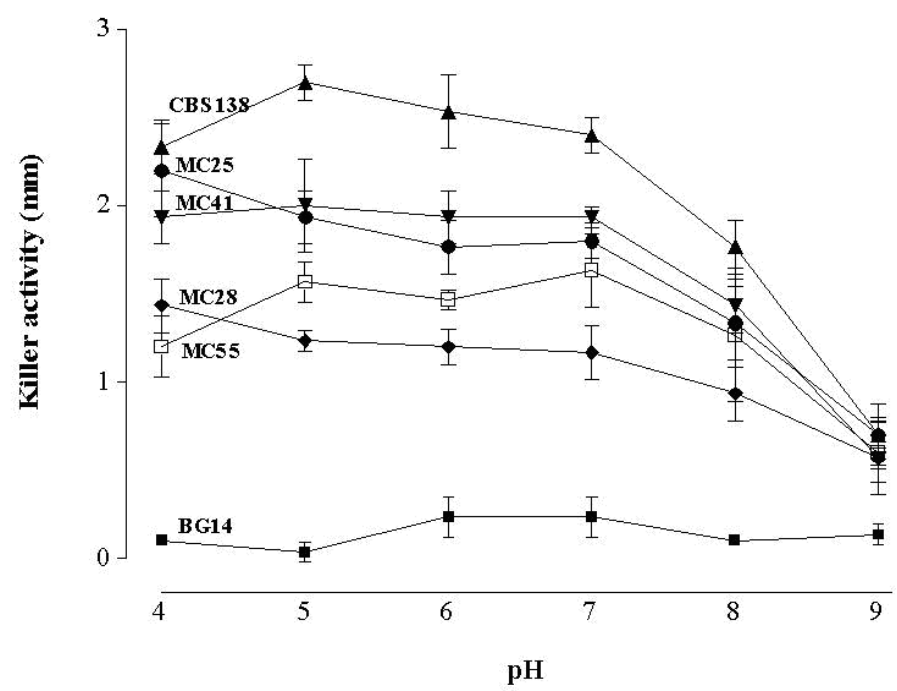

Figure 2. Effect of $\mathrm{pH}$ on stability of killer activity. Culture filtrates were adjusted to the appropriate $\mathrm{pH}$ (4-9) with $0.1 \mathrm{M}$ citrate phosphate buffer and kept at $4^{\circ} \mathrm{C}$. Determination of killer activity was assayed. $\mathrm{n}=5$.

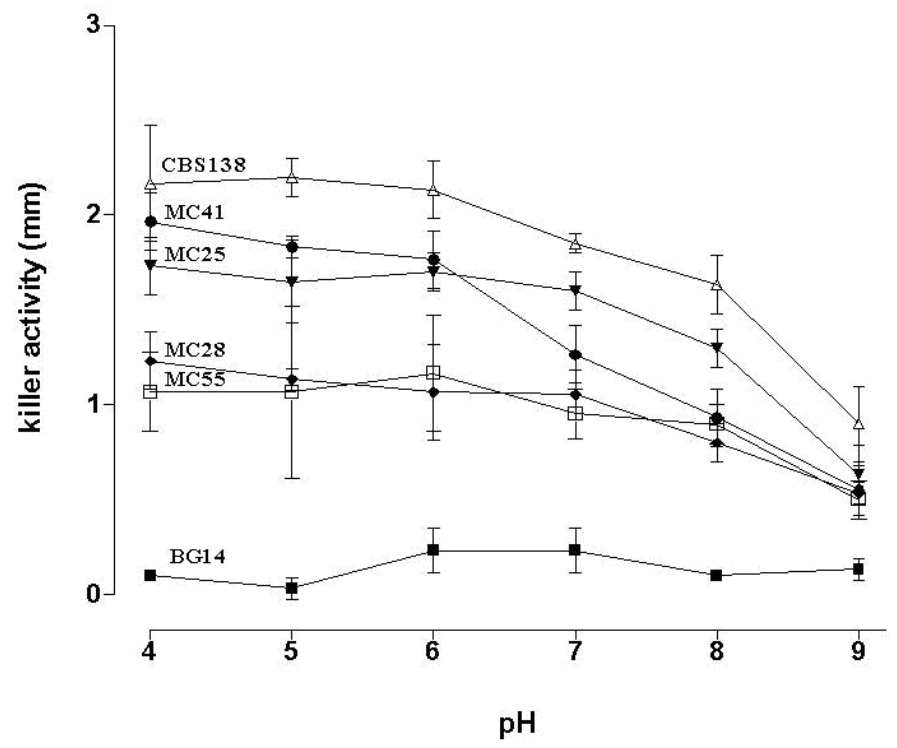

Figure 3. Effect of the $\mathrm{pH}$ in the $C$. glabrata growth media on the production of killer activity. YPD aliquots were adjusted to the appropriate $\mathrm{pH}$ values (4-9) with $0.1 \mathrm{M}$ citrate phosphate buffer. Killer activity was assayed. $n=4$.
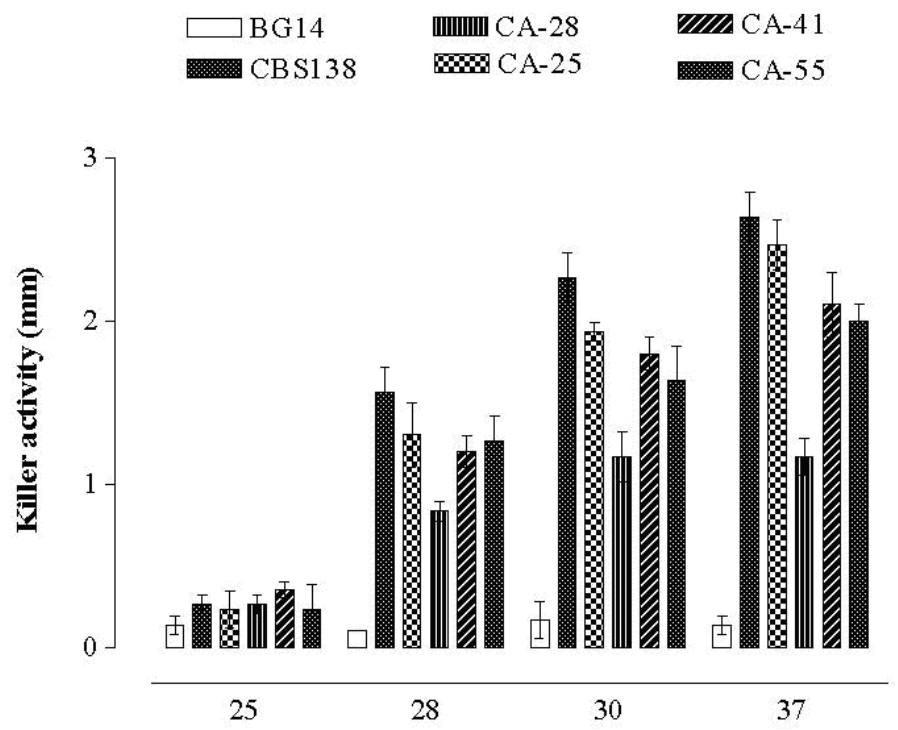

Figure 4. Temperature effect on killer activity. The killer activity was assayed using culture filtrates at $\mathrm{pH} 7.0$ and incubated at $25,28,30$ and $37^{\circ} \mathrm{C}$ for 72 h. $\mathrm{n}=4$.

\section{Plasmid isolation and curing}

It has been previously reported that UV irradiation induces 
removal extrachromosomal genetic elements as dsRNA and dsDNA that encoded killer phenotype $(27,28)$. This killer plasmids loss by UV is by DNA damage and formation of pyrimidine dimmers that disturbs DNA replication, RNA synthesis and plasmid replication (7). In order to test whether C. glabrata killer yeast contain extrachromosomal genetic elements, total nucleic acids were purified and analyzed by agarose gel electrophoresis. None of the killer clinical isolates of C. glabrata or CBS138 reference strain presented any extrachromosomal band of nucleic acids. Only in our positive control S. cerevisiae S288C strain, an extrachromosomal band of about $4.5 \mathrm{~kb}$ was found as described (Fig. $5 \mathrm{~A}$ ) (28). In order to cure possible extrachromosomal nucleic acids not identified by agarose gel electrophoresis, we irradiated with UV all four killer $C$. glabrata clinical isolates at $20,000 \mu \mathrm{J} / \mathrm{cm} 2(87-98 \%$ of killing). Surviving colonies from all four clinical isolates were tested for killer activity, and all of them, as well as surviving colonies from CBS138 strain retained the killer activity after the exposition to UV (data no shown). These data strongly suggest that the gene is localized in the chromosome.

M $\quad$ BG14 $\quad$ CBS138 $\$ 288 C$ MC25 MC28 MC41 MC55

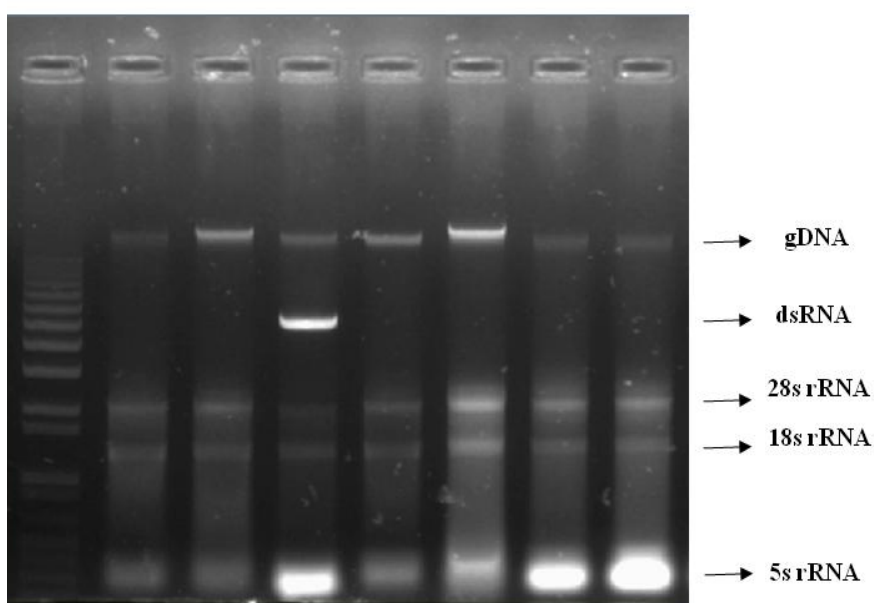

Figure 5. Detection of total nucleic acids isolated from $C$. glabrata clinical isolates by agarose gel electrophoresis. BG14 (killer negative), CBS138 (killer yeast), S. cerevisiae (contain a $4.5 \mathrm{~kb}$ dsRNA plasmid used as positive control). gDNA, genomic DNA. dsRNA, double stranded RNA. $n=3$.

\section{Killer toxin from $C$. glabrata induces DNA fragmentation and loss of viability.}

Incubation of sensitive yeast $S$. cerevisiae with killer toxin extracts results in gradual loss of viability after 24,48 and $72 \mathrm{~h}$ treatment. The relative CFU decrease is time dependent in the clinical isolates, but the loss of viability is more pronounced with killer toxin from CBS138 (Fig. 6). To determine if the loss of viability occurs through induction of DNA fragmentation in the sensitive yeast strain of $S$. cerevisiae (in an apoptotic-like pathway), DNA was extracted from sensitive yeast $S$. cerevisiae treated with killer toxin for $72 \mathrm{~h}$ and resolved in an agarose gel. Figure 7 shows DNA fragmentation (visible as DNA ladders) of varying sizes only in cells treated with killer culture extracts but not in control cells treated with used media from non-killer C. glabrata clinical isolates (Fig. 7 compare lanes 5-9 with lanes 1-3).

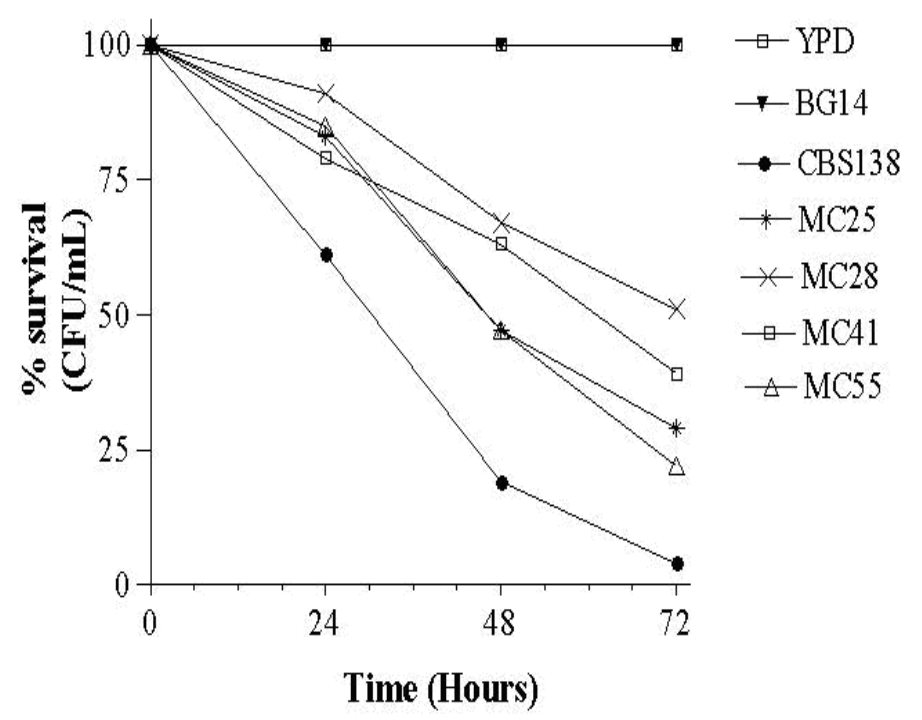

Figure 6. Sensitivity of $S$. cerevisiae to killer extract from $C$. glabrata clinical isolates. A, \% survival (CFU \%) of $S$. cerevisiae in liquid media incubated with killer extracts, log CFU (\%) is the relative number of colony forming units; time $0=5 \times 106$ cells. CFU was measured at intervals by diluting and plating on YPD. $n=5$. 


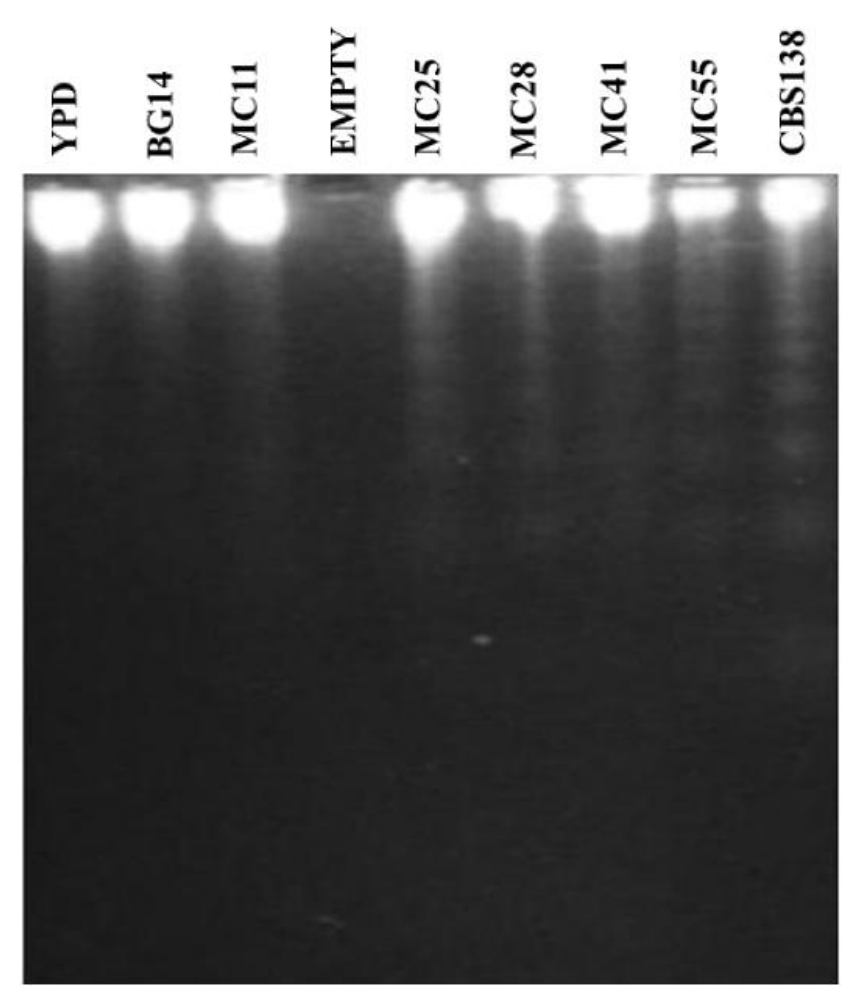

Figure 7. Survival of $S$. cerevisiae and DNA fragmentation induced by killer toxins from $C$. glabrata clinical isolates. Agarose electrophoresis with total DNA from S. cerevisiae treated with killer extracts for $72 \mathrm{~h}$ at $30^{\circ} \mathrm{C} . \mathrm{n}=3$.

\section{DISCUSSION}

The present study describes the killer phenotype from a collection of $C$. glabrata clinical isolates, our data showed low occurrence $(6.25 \%)$ of killer yeast from a collection of 64 clinical isolates. This low prevalence of killer pathogenic strains has been previously reported. Kandel and Stern (10), screening 234 strains from Cryptococcus, Torulopsis, Candida, and Trichosporon and found killing activity only in 5\% Candida and $7 \%$ in Cryptococcus, therefore it appears that occurrence of pathogenic killer yeast is limited.

The majority of killer yeast did not produce killer toxin at $\mathrm{pH}$ values higher than $\mathrm{pH} 5.6$ and the optimal $\mathrm{pH}$ for killer activity oscillates between 4 to 4.6 (20). We found that CBS138 and our C. glabrata clinical isolates produce killer toxin over a wide range of $\mathrm{pH}$ and the optimal killer activity was at $\mathrm{pH} 4$ to 8 at $37^{\circ} \mathrm{C}$, in agreement with Yokomori et al. (29) where it is shown that SW-55 killer toxin from genus Candida had killer activity over a broad $\mathrm{pH}$ range and temperature. These properties of C. glabrata killer proteins could have potential antimycotic activity against fungal pathogens, although further studies are necessary. In agreement with previous studies where it was shown that the killer protein from Candida sp SW-55 is encoded in the chromosome (29), we found that none of the clinical isolates of C. glabrata with killer activity have extrachromosomal molecules, suggesting that the genes responsible for this activity are encoded in the genome (23). Furthermore, the fact that killer phenotype was not cured with UV radiation strengthens this notion (Data no shown).

In yeast, apoptotic cell death can be induced by different exogenous and intrinsic stresses like $\mathrm{H}_{2} \mathrm{O}_{2}$, UV irradiation, acetic acid, cell aging, and high pheromone concentration (4, 8, 11-13, 24). Based on the data presented here, we suggest that killer yeast toxins from $C$. glabrata clinical isolates and CBS138 decrease viability of $S$. cerevisiae sensitive strain, probably through an apoptotic cell death as suggested by DNA fragmentation observed in sensitive yeast. This process has been reported previously with killer toxin $\mathrm{k} 1$ and k28 where apoptosis is mediated through yeast caspase Ycalp and the generation of ROS (21). More studies are necessary to analyze the apoptotic cell mechanism induced by $C$. glabrata killer toxins.

\section{ACKNOWLEDGEMENTS}

This study had financial support from Instituto Potosino de Investigación Científica y Tecnológica (IPICYT) and CONACyT grants No. CB-2005-48304 to ICN and CONACyT-Salud No. 13927 to APN and PROMEP-SEP grant No. PROMEP/103.5/10/5006 and from Instituto de Salud Pública of Universidad Veracruzana grants POA 2010-2011 to OAH. The authors also wish to thank Alejandro Martinez 
Murillo for his contribution to this study and Irene Xochihua Rosas for proofreading.

\section{REFERENCES}

1. Bendova, O. (1986). The killer phenomenon in yeasts. Folia Microbiol., 31, 422-33.

2. Cormack, B.P.; Falkow, S. (1999). Efficient homologous and illegitimate recombination in the opportunistic yeast pathogen Candida glabrata. Genetics., 151, 979-987.

3. Coyle, B.; Kinsella, P.; McCann, M.; Devereux, M.; O'Connor, R.; Clynes, M.; Kavanagh, K. (2004). Induction of apoptosis in yeast and mammalian cells by exposure to 1,10-phenanthroline metal complexes. Toxicol In Vitro., 18, 63-70.

4. Del Carratore, R.; Della, C.C.; Simili, M.E.; Taccini, M. Scavuzzo, and S. Sbrana. (2002). Cell cycle and morphological alterations as indicative of apoptosis promoted by UV irradiation in S. cerevisiae. Mutat Res., 513, 183-91.

5. Fidel, P.L.; Vazquez, J.A.; Sobel, J.D. (1999). Candida glabrata: review of epidemiology, pathogenesis, and clinical disease with comparison to C. albicans. Clin Microbiol Rev., 12, 80-96.

6. González, G.M.; Elizondo, M.; Ayala, J. (2008). Trends in species distribution and susceptibility of bloodstream isolates of Candida collected in Monterrey, Mexico, to seven antifungal agents: results of a 3-year (2004 to 2007) surveillance study. J Clin Microbiol., 46, 29022905.

7. Gunge, N.; Takahashi, S.; Fukuda, K.; Ohnishi, T.; Meinhardt, F. (1994). UV hypersensitivity of yeast linear plasmids. Curr Genet., 26:369-373.

8. Herker, E.; Jungwirth, H.; Lehmann, K.A.; Maldener, C.; Frohlich, K.U.; Wissing, S.; Buttner, S.; Fehr, M.; Sigrist, S.; Madeo, F. (2004). Chronological aging leads to apoptosis in yeast. J Cell Biol., 164, 501-7.

9. Kagan, B.L. (1983). Mode of action of yeast killer toxins: channel formation in lipid bilayer membranes. Nature., 302, 709-11.

10. Kandel, J.S.; Stern, T.A. (1979). Killer phenomenon in pathogenic yeast. Antimicrob Agents Chemother., 15, 568-71.

11. Laun, P.; Pichova, A.; Madeo, F.; Fuchs, J.; Ellinger, A.; Kohlwein, S.; Dawes, I.; Frohlich, K.U.; Breitenbach, M. (2001). Aged mother cells of Saccharomyces cerevisiae show markers of oxidative stress and apoptosis. Mol Microbiol., 39, 1166-73.

12. Lavaniegos-Sobrino, M.T.; Ramírez-Zavaleta, C.Y.; Ponce de León, A.; Sifuentes-Osornio, J.; Bobadilla-Del Valle, M.; Rangel-Cordero, A.; De Las Peñas, A.; Castaño, I. (2009). Genotyping of the MTL loci and susceptibility to two antifungal agents of Candida glabrata clinical isolates. Mem Inst Oswaldo Cruz., 104, 775-82.

13. Ludovico, P.; Sousa, M.J.; Silva, M.T.; Leao, C.; Corte-Real, M. (2001). Saccharomyces cerevisiae commits to a programmed cell death process in response to acetic acid. Microbiology., 147, 2409-15.

14. Madeo, F.; Frohlich, E.; Ligr, M.; Grey, M.; Sigrist, S.J.; Wolf, D.H.; Frohlich, K.U. (1999). Oxygen stress: a regulator of apoptosis in yeast. $J$ Cell Biol., 145, 757-67.

15. Messer, S.A.; Diekema, D.J.; Boyken, L.; Tendolkar, S.; Hollis, R.J.; Pfaller, M.A. (2006). Activities of micafungin against 315 invasive clinical isolates of fluconazole-resistant Candida spp. J Clin Microbiol., 44, 324-6.

16. Muller, H.; Hennequin, C.; Gallaud, J.; Dujon, B.; Fairhead, C. (2008). The asexual yeast Candida glabrata maintains distinct a and alpha haploid mating types. Eukaryot Cell., 7, 848-58.

17. Nguyen, M.H.; Yu, V.L.; Morris, A.J. (1996). Candida infection of the arteriovenous fistula used for hemodialysis. Am J Kidney Dis., 27, 596-8.

18. Pertowski, C.A.; Baron, R.C.; Lasker, B.A.; Werner, S.B.; Jarvis, W.R. (1995). Nosocomial outbreak of Candida albicans sternal wound infections following cardiac surgery traced to a scrub nurse. J Infect Dis., $172,817-22$.

19. Pfaller, M.A.; Boyken, L.; Hollis, R.J.; Kroeger, J.; Messer, S.A.; Tendolkar, S.; Diekema, D.J. (2008). In vitro susceptibility of invasive isolates of Candida spp. to anidulafungin, caspofungin, and micafungin: six years of global surveillance. J Clin Microbiol., 46, 150-6.

20. Polonelli, L.; Conti, S.; Gerloni, M.; Magliani, W.; Chezzi, C.; Morace, G. (1991). Interfaces of the yeast killer phenomenon. Crit Rev Microbiol., 18, 47-87.

21. Reiter, J.; Herker, E.; Madeo, F.; Schmitt, M.J. (2005). Viral killer toxins induce caspase-mediated apoptosis in yeast. $J$ Cell Biol., 168, 353-8.

22. Richter, S.S.; Galask, R.P.; Messer, S.A.; Hollis, R.J.; Diekema, D.J.; Pfaller, M.A. (2005). Antifungal susceptibilities of Candida species causing vulvovaginitis and epidemiology of recurrent cases. $J$ Clin Microbiol., 43, 2155-62.

23. Schmitt, M.J.; Breinig, F. (2002). The viral killer system in yeast: from molecular biology to application. FEMS Microbiol Rev., 26, 257-76.

24. Severin, F.F.; Hyman, A.A. (2002). Pheromone induces programmed cell death in S. cerevisiae. Curr Biol., 12, R233-5.

25. Starmer, W.T.; Ganter, P.F.; Aberdeen, V.; Lachance, M.A.; Phaff, H.J. (1987). The ecological role of killer yeasts in natural communities of yeasts. Can J Microbiol., 33, 783-96.

26. Walker, G.M.; McLeod, A.H.; Hodgson, V.J. (1995). Interactions between killer yeasts and pathogenic fungi. FEMS Microbiol Lett., 127, 213-22.

27. Wickner, R.B. (1979). The killer double-stranded RNA plasmids of yeast. Plasmid., 2, 303-22.

28. Wickner, R.B. (1983). Killer systems in Saccharomyces cerevisiae: three distinct modes of exclusion of M2 double-stranded RNA by three species of double-stranded RNA, M1, L-A-E, and L-A-HN. Mol Cell Biol., 3, 654-61.

29. Yokomori, Y.; Akiyama, H.; Shimizu, K. (1988). Toxins of a wild 
Candida killer yeast with a novel killer property. Agric Biol Chem., 52, 2797-2801.

30. Young, T.W.; Yagiu, M. (1978). A comparison of the killer character in different yeasts and its classification. Antonie Van Leeuwenhoek., 44, 5977.

(cc) BY-No 1 All the content of the journal, except where otherwise noted, is licensed under a Creative Commons License 